\title{
Wolf transplant could reset iconic island study
}

\section{US government proposes introducing more wolves to Isle Royale as population dwindles.}

\section{BY EMMA MARRIS}

$\mathrm{T}$ he world's longest-running study of predators and prey is on the endangered list - but it could soon get a reprieve from the US government.

Scientists have been charting the changing fortunes of wolves and moose on Isle Royale in Lake Superior for nearly 60 years, but a sharp decline in the wolf population now reduced to just two closely related animals - has threatened to end the project. Now, after years of debate, the US agency that manages the island in Michigan has proposed introducing up to 30 wolves from the mainland.

If the National Park Service goes through with the plan introduced on 16 December, it would create a new population of wolves. But the 'genetic rescue' long advocated by scientists hoping to save the island's inbred wolf pack now seems out of reach. Isle Royale's remaining wolf pair has little chance of producing healthy pups, because the male is the father of the female and they have the same mother. The animals' only known offspring was visibly deformed and died young.

"Unless something is done, you are going to lose wolves from Isle Royale," says Matthew Gompper, a carnivore specialist at the University of Missouri in Columbia who helped the park service to solicit expert input for its plan. "Ecologically, they are just a relict on the island. Moose are skyrocketing and we are seeing changes to the plant community."

\section{WILD CYCLE}

The park service's plan - which is open for public comment until 15 March - analyses several different scenarios for the next 20 years, from letting Isle Royale's wolves die out to adding wolves whenever the population gets too inbred. The agency favours "Alternative B", which would add $20-30$ wolves within 5 years, and then leave the island alone for another 15.

But shoring up the wolf population may not be enough to prevent Isle Royale's ballooning moose population from reshaping the island's ecosystem. Moose are eating balsam fir so heavily that the species could largely disappear, along with aspen, birch and mountain ash trees - turning a closed-canopy forest into an open spruce savannah.

John Vucetich, a population biologist who is one of the study's two principal investigators, worries that relocating a large number

of moose ticks and a single wolf crossing the frozen lake from the mainland and bringing his genes with him.

On some level, the introduction of new wolves by humans would be just the latest of these contingent events, says Vucetich, who favours such 're-wolfing'. But others oppose the plan as being inappropriate for Isle Royale, a national park where $99 \%$ of the land is designated as wilderness - so the federal government is required to preserve its wild character.

\section{ON THIN ICE}

"This is a slippery slope," says Kevin Proescholdt, conservation director of Wilderness Watch in Minneapolis, Minnesota. He predicts that adding wolves to Isle Royale will open the door to further manipulation of the ecosystem, because many of the factors that led the current wolf population to dwindle - including disease and climate variability could do the same to a reinforced population.

Those who support adding wolves to the island admit that the population may eventually need to be topped up again, especially because climate change has

of wolves to the island within the next five years won't save the balsam fir. "When the moose population has been growing at $22 \%$ per year like it has for the past 4 years, that is not something you stop on a dime," says Vucetich, who is based at Michigan Technological University in Houghton. "That is a freight train."

It will take about five years after wolves return to determine whether the new predators can save the balsam fir, he adds.

Results from the Isle Royale study, which began in 1958, have underscored the importance of unpredictable events to predator-prey population trends. Instead of neatly oscillating boom and bust cycles as wolves overeat moose, then starve and allow their prey to repopulate, the island's moose and wolf populations have spiked and crashed in response to external factors. These include a virus transmitted from domestic dogs, explosions in the population reduced how often Lake Superior freezes solid. That is the only condition under which wolves can reach the island on their own.

But Rolf Peterson, the study's other principal investigator, notes that early proponents of the US national wilderness-protection system supported adding wolves to Isle Royale in the 1940s to control the moose population. That was before the wolves first crossed the frozen lake and introduced themselves to the island.

In 1944, conservationist Aldo Leopold made such a recommendation in a letter to the acting director of the park service - and foresaw the study that was to begin 14 years later. "Isle Royale must present a wonderful opportunity for long-time records on the interaction of moose and browse," Leopold wrote, "and if wolves are added, on the interaction of all three. I hope the Park Service will not overlook this opportunity." - 